\title{
Electric vehicle charging and end-user motivation for flexibility: a case study from Norway
}

\author{
Ida Marie Henriksen* ${ }^{*}$, William Throndsen, Marianne Ryghaug and Tomas Moe Skjølsvold
}

\begin{abstract}
Background: Norway is currently in the process of replacing internal combustion engine (ICE) vehicles with electric vehicles (EVs). A steadily increasing number of EVs being charged in the evening when the demand peaks are already high has added to the strain on local electricity grids. Smart charging is proposed as a solution to peak-load challenges of this kind, as it can delay charging until evenings and nights when demand peaks are generally low. However, current knowledge of the preferences and motivations of EV owners regarding the installation and use of smart chargers is lacking. Accordingly, the study aims to contribute an improved understanding in this respect.

Methods: The authors conducted a qualitative study based on semi-structured interviews, in which they gained information on householder's experiences following their participation in a pilot project to test smart charging of EVs. The interviews explored the interviewees' motivation for participating in the project, their experiences of using and charging EVs, and their thoughts on flexibility in the timing of EV charging. Interviews were recorded and transcribed verbatim, after which a domestication theory approach was employed to perform an in-depth analysis of the interview data.
\end{abstract}

Results: The analysis of the interviews revealed that the study participants had four motivations for participating in the smart charging demonstration project and engaging in the further use of smart charging: (1) the fire-safety aspect and speed of charging devices for EVs was better than charging from a socket; (2) they derived a broader interest in and more joy from using smart home technology; (3) attractive practical and economic benefits; and (4) the flexibility offered by smart charging had the potential to have a positive impact on physical comfort.

Conclusions: The study revealed key domestication processes unfolding in the Norwegian energy transition with the increasing numbers of EVs and the corresponding grid peaks. The findings clearly indicate that users' motivations go much further than simple economic rationalization, which should be of interest to policymakers, smart home developers, and all others that work with end-user flexibility in the grid.

Keywords: Flexibility, End users, Electric vehicles, Smart charging, Domestication theory

\section{Introduction}

As energy transitions unfold, new complexities emerge when changes across infrastructures and sectors affect one another $[1,2]$. Electricity grids are particularly prone

${ }^{*}$ Correspondence: Ida.marie.henriksen@ntnu.no

Department of Interdisciplinary Studies of Culture, Norwegian University

of Science and Technology (NTNU), Trondheim, Norway to being impacted by such dynamics. On the one hand, new and variable renewable energy production provides new challenges in terms of synchronizing the timing of the supply and demand of electricity [3-5]. On the other hand, the demand for electricity increases as sectors, such as transport, become electrified [6, 7]. These factors have resulted in increasing interest among policymakers and innovators who are working to make energy original author(s) and the source, provide a link to the Creative Commons licence, and indicate if changes were made. The images or other third party material in this article are included in the article's Creative Commons licence, unless indicated otherwise in a credit line to the material. If material is not included in the article's Creative Commons licence and your intended use is not permitted by statutory regulation or exceeds the permitted use, you will need to obtain permission directly from the copyright holder. To view a copy of this licence, visit http://creativecommons.org/licenses/by/4.0/. The Creative Commons Public Domain Dedication waiver (http://creativecommons.org/publicdomain/zero/1.0/) applies to the data made available in this article, unless otherwise stated in a credit line to the data. 
consumption more flexible [8-10] by reducing demand during peak-load hours and shifting it to other times of the day [11].

With the introduction of electric vehicles (EVs), charging constitutes a key site in the demand for electricity, as well as a new means whereby households that own EVs can contribute to grid flexibility. The research focus on those working to instigate flexible energy consumption by households has been aimed at providing economic signals, often in combination with technologies mediating those signals to guide individual households to adjust their energy consumption. This strategy for providing more flexible energy consumption has often been referred to as demand-side response (DSR) or demandside management (DSM) [12]. Most mechanisms of this type are based on the assumption that individuals' flexibility will be motivated by economic incentives and rational choices [13-15]. Furthermore, many approaches to smart charging have relied heavily on economic incentives as a key element in product design [16].

Social scientists have often problematized the focus on economic incentives and/or they have called for approaches that regard economic incentives as one of several situated elements in flexibility interventions [17]. As part of their problematizing, social scientists have found new ways to analyze schemes that are supposed to provide end-user flexibility [18], including focusing on the elements that constitute practices in everyday life [19-21]. Through such expansions, their focus has shifted from mainly addressing questions of how to implement DSR to exploring the unanticipated consequences of such mechanisms. For example, Powells and Fell [22] explore how price signals and technologies that promote flexible consumption of energy tend to reinforce existing social divisions. Following their observation that affluent people have both the technological means (e.g., electric vehicles, thermal loads, batteries) to capitalize on flexibility and the financial means to choose whether or not they want to participate, Powells and Fell developed the concept of "flexibility capital" to highlight that not everyone has the same ability to be flexible. Similarly, Johnson [23] uses the idea of "flexibility woman" to illustrate how household-related flexibility in less affluent homes tends to be highly gendered, whereas Fjellså et al. [24] note that young adults tend to have fewer opportunities for flexibility. Research on flexibility is important in order to draw attention to potential risks, unwanted impacts, and injustices that may be reinforced by the introduction of technologies.

Another approach taken by social scientists has been to perform reality checks on assumptions, such as the assumption that people are mainly motivated by economic gains, which tend to enter into the processes in the largely top-down driven implementation of smart energy technology for home users [25]. As many more technologies are envisioned and deployed in the home setting, and in more and more advanced iterations, it is increasingly important to evaluate to what extent technology development processes employ a salient user perspective vis-à-vis the more traditional economic and technological approaches to grid optimization.

Smart EV charging is one of the newer add-ons to the different configurations of smart home devices, and studies conducted to date have primarily focused on public expectations and desires for this technology. Delmonte et al. [26] found that EV owners in the UK were interested in smart charging if costs were reduced, if users could retain personal control, and/or if broader advantages to society were clear. Similarly, a study of a German demonstration project found that contributing to both the stabilization of the electricity grid and integrating renewables was an important motivation for most participants, alongside economic benefits [27]. It has also been shown that environmental benefits and the integration of renewables are important motivations for smart charging in the Netherlands [28].

In this paper we focus on a case in Norway, where the rapidly unfolding electrification of transport $[5,29]$ has resulted in a new local demand for flexibility. We investigate a case featuring flexible EV charging in order to explore how end-user flexibility stemming from either technological fixes or behavioral changes enters and modulates everyday life. This kind of demand-response (DR) technology has been rather immature in the last 10 years, and the issue of flexibility has been treated on conceptual level, with few empirical studies looking at actual implementation of, for instance, smart charging and its relation to flexibility work. Accordingly, in this paper we study the shaping of flexibility as individual processes in the use of smart charging of EVs by private households. We address the following research question: How are EV chargers domesticated, and what can this tell us about the potential for flexible end use of EV charging?

The following section presents some central aspects of EV policy and regulatory measures that pertain to the rather rapid deployment of EVs in Norway. Thereafter, a short presentation of the state of the art of smart grids and charging in Norway is given. "Domestication of the smart home charger" section describes the domestication theory approach, and it includes examples of how the approach can be applied to understand how a technology is appropriated, used, and made sense of by users. "Method and pilot description" section, the methods section, describes the pilot project and our research design, Finally, "Results and interpretation: domesticating smart charging-four motivations" section present the results 
and analysis, "Discussion" section is a discussion of our findings and "Conclusions" section the conclusions.

\section{Norwegian EV policy and smart charging}

In 2020, the share of physically delivered renewable power in Norway was $98 \%$ [30]. This indicates that to fulfill commitments to achieve emission reductions under the EU's Renewable Energy Directive and the Paris Agreement [31, 32], policies have mainly targeted the transport sector and increasing the share of electric mobility. Over the last 25 years, Norway has implemented a series of quite radical policies to stimulate the uptake of electric vehicles. The political goal has been that all new cars sold by 2025 should be either zero emission (electric or hydrogen) or low emission (plug-in hybrid). In recent years, EVs have become mainstream and a normalized element within Norwegian mobility culture [33]. In November 2020, more than 52\% of new cars sold were electric cars [34].

The rapid rate of EV adoption has contributed substantially to an increasing demand for local power capacity in Norway [35, 36]. Although EVs are very fuel-efficient and electrification of Norwegian car parks represents a modest $0.42 \%$ of the total electricity use in Norway [37], this can still impact local conditions where many new electrical appliances are added yearly to local, aging neighborhood grids, thus increasing the burden on them considerably. Thus, the increase in deployment of EVs has resulted in several new practical challenges, particularly those related to providing sufficient charging infrastructure for people living in apartment buildings, community housing, and other buildings that lack options for public parking.

The challenges have been exacerbated by stricter regulations and the advent of a responsible charging culture that stresses safety more than before $[38,39]$. In the early days of EVs in Norway, car owners would just simply plug their vehicle into a regular socket wherever one was found available and charge outside their home or in their own garage. However, where once familiar scenes of cords emerging through ground-floor or second-floor kitchen windows to bridge the gap between the car and access to the grid, safety concerns have now led many EV users to install dedicated EV charging stations [40,41]. The stations are a huge improvement in terms of fire safety, and they provide the added bonus of higher charging speeds. This has resulted in a mass market for different kinds of EV chargers in Norway. With regard to pilot studies, many actors, especially grid operators, are implementing EV chargers in all kinds of homes in order to employ their smart charging capabilities, thereby enabling them to provide not only safer and faster charging, but also load patterns that are sensitive to grid congestion.

One main difference between smart and conventional charging is the ICT possibilities linked to the chargers. The charger can be connected to the home energy management system (HEMS), or the home area network (HAN) of a smart electricity meter (as in the case study), which opens up the possibility of managing charging though demand response, either from the level of grid operators or by using automatic power management (APM). Thus, smart chargers can integrate EVs and charging schedules into smart home solutions (in the studied case, also via smart meters), thereby helping to reduce consumption peaks and potentially also electricity costs for EV owners. This is especially important given the prospect of Norway replacing the existing system of energy bills (whereby users pay by the kWh) with power tariffs (settled according to kW peaks). Recently, a market for solutions that manage EV charging and smart house solutions for customers has started to mature and to transform the energy retail sector into an arena for energy service providers that provide electricity to customers at one end and a portfolio of load profiles (households) at the other end.

\section{Domestication of the smart home charger}

In the study on which this paper is based, we employed a domestication theory approach $[42,43]$. In its first iteration, the theory was employed to understand how media technology involves active use rather than passive consumption [44]. At the time, the approach 'gave back' some long-lost agency to users of media technologies, that hitherto had been described mainly as passive consumers who were vulnerable to the risk-filled effects of media content [45]. The domestication theory approach is relevant for other technologies too, as it makes us less prone to blaming technological outcomes, whether successful or not, merely on the design of the technology itself [46]. In other words, it is useful when we are, as now, at a point in time when we need better knowledge about how to facilitate EV adoption.

Domestication is particularly useful for analyzing how technology becomes both part of and integrated into people's everyday lives. There are several examples of its use in the study of smart energy and smart home technologies [47, 48], and electric vehicles [49]. In our case, the domestication theory approach has enabled us to see how EV charging becomes part of household members' habits and routines, and their use of EVs and other appliances, whether old or new. More importantly, the domestication theory brings to the foreground how such micro-networks lead to the formation of relationships between humans, artifacts, knowledge, and institutions, 
and to the interplay and influence of people's everyday practices [42]. With the concept of domestication, we can further understand how, when opting to use an EV, people not only need to learn how driving an EV differs from driving a conventional car, but also about using a home charger to charge the battery, which is a different process from filling a gas tank. In other words, the charging habits of EV owners are part of their domestication in the use of EVs.

Thus, domestication theory stresses the importance of the symbolic value of technologies, not just their function [50]. In short, a domestication analysis considers three aspects of technology appropriation and use: the symbolic, the practical, and the cognitive. These aspects of technology appropriation and use are embedded in scripts and revealed by the way the scripts are read and the objects are used [51, 52]. The symbolic aspect deals with how technology is understood, interpreted, and attributed meaning. Practical aspects of technology use address the actual use of a technology, its affordance (or lack thereof), or whether the use of it is considered to achieve the expected results successfully. Lastly, cognitive aspects are related to learning about how and in what ways we are given a chance to get to know a technology, how we come to learn or teach ourselves or one another how to use it, and whether learning occurs at all [43].

Domestication theory enables us to become attuned to the practical, cognitive, and symbolic aspects of use, and can qualify negotiations between users and technology in those three domains. Although not hierarchical, successful domestication is qualified only by the presence of mutually adaptive activities in all three domains [46]. Finally, domestication is rarely an isolated undertaking; it always happens in relation to the social and technological surroundings.

Previous studies have found that EV users can become more conscious of their own energy consumption and more environmentally sensitive through EV domestication processes $[49,53]$, also in cases when vehicles have been purchased primarily due to economic motivations. Furthermore, experiences of using EVs have played a role in the domestication of other energy technologies, such as solar panels [54]. Thus, EVs and driving practices have become part of a broader repertoire of ideas and rationalities, wherein material elements such as the location of chargers, symbolic understandings of what a car is, and ways of using the car change over time. Hence, as EVs are resulting in new electricity peaks, domestication allows researchers to follow how these new conditions render new paths of domestication possible. However, to identify potential ways forward, there is also a need to understand how EV users themselves understand and make sense of smart charging, and whether they are willing to test it. In short, we need to understand how users domesticate smart charging. This paper aims to contribute to such understandings.

\section{Method and pilot description}

In Norway, 97\% of fuse boxes have a smart meter and many EV owners have their own parking space at home $[55,56]$. As mentioned in "Introduction" section, grid companies in Norway are facing a substantial increase in EVs drawing power from the grid, and a consequent need for costly upgrades to the low-voltage network. Thus, the goal of the pilot study reported in this paper was to test solutions that could aid in postponing investments and at the same time provide EV charging as needed. The innovation tested in the pilot was designed to enable the smart meter to communicate with the EV charger and to enable the user to avoid charging at peak hours. The charger in question could connect to all kinds of EVs. However, the most common brand used in the pilot was the BMW i3, followed by Mercedes, Tesla, and Hyundai.

The grid company that was involved in the pilot recruited participants through an announcement in a newsletter. Participants were incentivized by the offer of a 50\% discount on a new EV charger. In 2019, chargers were quite expensive (around EUR 1800-2000). Due to technical issues, the smart part of the charging was not up and running before 2020 and thus after we had conducted our interviews. Therefore, the focus of this paper is on the users' motivation for opting to use smart charging and direct load control of the EV charging.

\section{Research design}

We used a qualitative research design. The research was based on semi-structured individual interviews with 14 participants and e-mail correspondence with 1 participant from the 18 households that participated in the pilot; the remaining three participants did not respond to our invitation. The households were users of smart EV chargers in Stavanger, a town with ca. 130,700 inhabitants in western Norway. The participants gave their written consent to participate in our study when they signed up to the pilot, and therefore the demo-site owner (the local grid operator) was able to provide us with the home address of each participant. Each interview lasted ca. $1 \mathrm{~h}$, and was audio-recorded and subsequently transcribed verbatim. More details of the interviewed participants are listed in Table 1. The anonymity of participants has been preserved.

Qualitative interviews are intended to provide in-depth knowledge and thick descriptions relating to the topic of study. We set out with the aim of discovering each participant's motivation for participating in the pilot. Originally, we had intended to gain insights into their smart charging 
Table 1 Description of the interviewed participants, their households, and their reasons for participating in the pilot

\begin{tabular}{|c|c|c|c|c|c|}
\hline Interviewee & $\begin{array}{l}\text { Gender and age } \\
\text { of interviewee }\end{array}$ & $\begin{array}{l}\text { Number of } \\
\text { persons in } \\
\text { household }\end{array}$ & $\begin{array}{l}\text { Cars in the } \\
\text { household }\end{array}$ & Preferred charging site & Main motivation to participate in the pilot \\
\hline 1 & Man & 4 & $\begin{array}{l}1 \mathrm{EV} \\
1 \text { diesel }\end{array}$ & Home, but also used elsewhere & Charger price \\
\hline 2 & Man & 4 & $\begin{array}{l}1 \mathrm{EV} \\
1 \text { hybrid }\end{array}$ & Home & Charger price \\
\hline 3 & Man & 2 & $1 \mathrm{EV}$ & Home & Charger price and technology interest \\
\hline 4 & Man & 2 & 1 hybrid & Home & Charger price \\
\hline 5 & Woman & 2 & 2 hybrid & Home & Charger price \\
\hline 6 & Man & 4 & $\begin{array}{l}1 \mathrm{EV} \\
1 \text { diesel }\end{array}$ & Home & Charger price and technology interest \\
\hline 7 & Man & 3 & $2 \mathrm{EV}$ & $70 \%$ home; $30 \%$ work & Charger price \\
\hline 8 & Man & 3 & $3 \mathrm{EV}$ & Home & Technology interest \\
\hline 9 & Man & 4 & $\begin{array}{l}1 \mathrm{EV} \\
1 \text { diesel }\end{array}$ & Home & Fire safety and technology interest \\
\hline 10 & Man & 5 & $\begin{array}{l}1 \mathrm{EV} \\
1 \text { gasoline }\end{array}$ & Home, but not every day & Fire safety and technology interest \\
\hline $\begin{array}{l}11 a \\
11 b\end{array}$ & $\begin{array}{l}\text { Woman } \\
\text { Man }\end{array}$ & 4 & $1 \mathrm{EV}$ & Home & Charge faster and fire safety \\
\hline 12 & Man & 3 & 1 hybrid & & Charger price \\
\hline 13 & Woman & 4 & $\begin{array}{l}1 \mathrm{EV} \\
1 \text { diesel }\end{array}$ & Home & Fire safety, technology interest, and price \\
\hline 14 & Man & 2 & $\begin{array}{l}2 \mathrm{EV} \\
1 \text { diesel }\end{array}$ & Home & Price and technology interest \\
\hline $\begin{array}{l}15 \\
\text { e-mail }\end{array}$ & Man & 5 & $\begin{array}{l}1 \mathrm{EV} \\
1 \text { diesel }\end{array}$ & Daily at work & Price and it was a good project \\
\hline
\end{tabular}

experiences, but due to technical issues that caused delays in the project the smart charging user interface was not operational at the time of when the interviews were held in January and February in 2019. In addition to not being smart chargers (i.e., with load and price forecasting and machine learning capabilities), the chargers used by the participants in the pilot were still under development.

In the in-depth interviews we asked the following questions, among others: "What made you sign up for this pilot?" "What charging solutions did you use before?" and "Do you schedule/program the car's charging hours?" The interviewees' quotes in this paper have been translated by the authors from Norwegian into English. Our analysis is inspired by grounded theory, which is guided by an inductive approach that treats empirical results as the foundation of analysis [57]. The goal of such analyses is not to generalize statistically, but rather to provide in-depth insights, which in our case is insights into different motivations for using domestication EV chargers.

\section{Results and interpretation: domesticating smart charging-four motivations}

As delays in the development of the smart charging ICT platform occurred late in the project, many participants were initially motivated to participate in the pilot by the prospect of saving money on a state-of-the-art wall-mounted EV home charger at half-price. The offer resulted in the pilot having all participants fully signed up within half an hour of the grid company's announcement of the offer in an e-mailed newsletter. This indicates that a relevant financial incentive was important and that many recipients of e-mails from the network were sufficiently interested to open the emails. However, the recruitment method introduces a potential bias, as it can be expected to attract those who are most interested, or who have what Powells and Fell [22] call the most flexibility capital. While financial incentives are important, earlier research indicates that price is often only one element in a broader configuration of elements that constitutes the interest in novel energy technology and pilot project participation [17]. Hence, to understand the popularity of the pilot, we needed to probe beyond the initial focus on economic aspects. Our analysis revealed four different, albeit somewhat overlapping, motivations for participation in the pilot and adoption of the use of a smart charger: (1) fast and fire-safe charging; (2) technological interest and enjoyment; (3) practical and economic concerns, and (4) flexibility as a means to enhance physical comfort. Each motivation is described in more detail in "Fast and firesafe charging", "Technological interest and enjoyment", 
"The practical and economic concerns" and "Flexibility as a means to enhance physical comfort" sections.

\section{Fast and fire-safe charging}

One important reason for participants wanting to procure a charger for their household was their concern for the lack of fire safety inherent in the practice of charging from a regular outlet. Even though the fuse on the circuit that could be used to couple and charge an EV would be sufficient in many cases ( $\max 10 \mathrm{~A}$ ), the impedance added to a long cable could risk adding to the amperage requirements without any immediate indication, resulting in cables overheating and eventually catching fire. Stories of such incidences had been more or less a recurring theme in news media, in step with increased EV adoption in Norway, and eventually the Directorate for Civil Protection and Emergency Planning (DSB) [38] and the Norwegian Electrotechnical Committee [39] issued stark recommendations on how to charge EVs safely. This included advice to install a dedicated charger, but there were still several concerns. In cases where it is necessary to use a regular outlet, an EV owner needs to make sure that it is earthed, and that is on a separate circuit with at minimum a 10 A fuse. Furthermore, a connector (usually one that comes with the car as standard equipment) can be damaged due to its weight, and therefore it is recommended that it should be hung on a hook or stored in a basket. Otherwise, according to Directorate for Civil Protection and Emergency Planning (DSB), the optimal solution is a home charging station [38]. Such a device is usually fitted with a 16 A or 32 A fuse, but up to $63 \mathrm{~A}$ fuses are used in some cases. As long as the local grid can cope, installers can accommodate high levels of power consumption by users by adjusting chargers to deliver the maximum possible electrical current according to the make and model of a car. The above-mentioned points illustrate how domestication is seldom done in isolation, but is an undertaking whereby actors such as news media (see e.g., [58]), and government regulators partake in shaping societal awareness of EV charging and safety, and/or the cognitive and practical dimensions of domestication. Many of the EV owners who participated in the study were aware of the DSB's recommendations but had not yet purchased a charger station due to their relatively high price. Hence, when an offer of a half-price charger appeared in an e-mail, they immediately responded. The following dialogue between a couple from one household explains why they had acquired a charger:

\footnotetext{
Man: Better charging. Faster.

Woman: We had an EV like the one [the man] has, so I often was able to borrow it and thought it was a safe solution.
}

\author{
Interviewer: In terms of fire safety? \\ Woman: Yes. \\ Man: If you have extension cables over a long period \\ of time, they can get worn. (Interviewees 11a and \\ 11b)
}

The charging station was considered more effective and simply better to use than an ordinary outlet: "I've come to realize it is much safer to use it. We can control it much, much more than with a regular outlet, when considering the fire hazard" (Interviewee 13). Interviewee 5 said "I had just bought an electric car and was of the opinion that if you have an electric car you should have a charger in the house and not charge on a regular outlet," thus indicating she would think about the car and charger in terms of a responsible, packaged solution. The quote also shows how her attitude towards charging at a regular outlet was clearly connected to the risk of fire. She (Interviewee 5) clearly considered it improper to not charge from a dedicated charging station, even though at the same time it was not in any way illegal or uncommon to do so. Thus, charging in a fire-safe manner was common practice for some interviewees.

\section{Technological interest and enjoyment}

In contrast to the somber safety concerns of some interviewees, other EV users had signed up to join the pilot purely out of a keen interest in technology and the prospect of enjoyment from the use of smart technology-an important motivation that has been found in other studies of other smart homes and smart energy technologies (e.g., [59]). The users ascribed the motivation to their interest in mixing, matching, and playing with smart home technologies. For example, Interviewee 10 said "I like to control the thing myself [...] I think it is fun to optimize things [...]. I think the technology and project is exciting." Another interviewee stated outright that offers of technology in general, such as the smart charger offered through the pilot project, were not interesting if he could not play with the technology: "I don't pay for it if I cannot play with it [...] It is when you can 'knock yourself out' and try things and do things that you find interesting solutions [...] I do not like technological solutions that are locked to one system or brand" (Interviewee 3). The described kind of creative playfulness is indicative of another, entirely different kind of motivation than the somber safety aspect. However, the EV owners with an interest in technology and enjoyment encountered problems with lock-ins, bundling, and any kind of proprietary gadget or app that restricted their DIY aspirations, as they were unable to mix and match gadgets to achieve creative solutions and optimal conditions. In other words, if a piece of technology did not offer such 
users the prospect of freely configuring it into an already existing technical landscape in their household, it would never be considered for appropriation.

Even though sometimes the consequences of the smart and technical endeavors to allow for playfulness could, for instance, constitute a kind of load shifting, this often was not the main interest and did not seem to be the goal of the user's engagement with the technology. Rather, the driving force was the prospect of the fun to be had from exploring technology and making smart solutions work, and any grid optimization result would be coincidental. This indicates that such EV owners acquire a sense of joy from tinkering and being in control of their technical equipment-a phenomenon that is not studied further in this paper. Enjoyment derived from the ability to play also functions as a motivation for some users of EV chargers who are part of the DIY communities on the Internet, as described by [60], but meshes poorly in the absence of a personality that identifies strongly as technologically avant-garde or technologically competent, or if the person lacks sufficient income to spend on technology. In our case, some study participants' playfulness motivated them to sign up for the pilot and obtain a smart EV charger, while load shifting might have become a second-order effect of having fun, and be interpreted as belonging to the symbolic dimension of the domestication of what kind of meaning an EV charger can have for such participants. The charger was appropriated into existing network of gadgets, and as part of a hobby and area of expertise it reflected the identity of the users.

\section{The practical and economic concerns}

The practical rationale for smart charging as a motivation for using smart chargers was initially elicited by the discount on the charger, but when the participants were asked to elaborate we gained the impression that signing up for the pilot was motivated by the prospect of installing smart home technology in the form of smart chargers because first and foremost it was practical to do so. For example, one participant reasoned "because it is smart, not cool" (Interviewee 2), while another compared the installation of the EV charger with the installation of a smart thermostat in the bathroom, which was to stabilize the floor temperature, not to save electricity. It first appeared that the participant seemed interested in the technology, but did not have the same sense of enjoyment and fun in the optimization of the smart house as the participants discussed in "Technological interest and enjoyment" section. By comparison, those with practical concerns were more interested in ensuring that a problem was solved in the most practical way.

To some extent, there was also an element of economic interest among the participants, but one that differed from securing a good price for the charger itself. Such EV owners were more interested in the potential economic benefits of using a charger that only charged off-peak and when electricity was cheaper due to less demand. This kind of motivation can also be seen as a typical reflection of the "resource man" who assigns control by practicing "set-and-forget" [19], as described also by HarperSlaboszewicz [61]. We found this kind of motivation in the participants' descriptions of why EV charger users chose an EV when replacing their old car, which was simply because they gained more value for their money, given the many policy measures favoring EVs, such as tax reduction, free parking, permanent access to carpool lanes (also known as high-occupancy vehicle lanes), and free admission to toll roads.

\section{Flexibility as a means to enhance physical comfort}

When inquiring about charging habits, we found there were many different practices. Some participants charged their EV immediately after they returned home, while others charged their EV after "the last trip of the day" and yet others did so every 2nd or 3rd day simply because they drove less often. We also found that even if the charger was not smart capable at the time of our interview, some of the EV owners planned to use the companion app that came with the car in order to achieve a certain level of smartness. In some cases, users even manually set their car to start charging at night and then during off-peak times via the in-car interface. One EV owner explained that he did that because he wanted to alleviate grid congestion, but most of the others pointed out that they programed their charger to start charging at night because they wanted their car battery to be healthy. Another practical concern that influenced the participants' charging practices was their desire for physical comfort during wintertime:

Yes, when it is like it is in this time of year [...] it's normal to set it to charge and set it so that it's done in the morning. Then you have a preheated battery, [and] that's important in the winter, that the battery is preheated. (Interviewee 8)

To preheat the battery in wintertime in Norway was important for some of the EV owners, due to their expectations about battery health and battery-life expectancy (arguably one of the main concerns of the EV owners compared with owners of ICE vehicles). They claimed that as preheating would save the power in the battery, they would have a slight increase in driving range. However, nighttime charging and preheating afforded some degree of physical comfort too, as the EV would be warm before setting out in the morning: 
Well, the way I use the app is that I've set up the car so that it will charge in a certain period. It'll preheat to a certain time or another, and that's automatic, or I just set it up to be warm at 07:21 or thereabouts. And then it's been charging for three hours. (Interviewee 3)

Another EV owner explained that he had timed the charging because his wife preferred the car to be preheated before she used it in the morning. Preheating is also commonly done with ICE vehicles in wintertime in Norway, with the aid of an electric engine heater. This is both fuel-efficient and 'healthy' for the engine, as well as providing comfort in the morning, and it is an established part of the Norwegian comfort-oriented driving culture [33]. Among our EV users, some preheated their EV while it was charging, but others used a traditional car heater to avoid draining the battery. In short, preheating is a way of providing comfort and can also be a motivation to do load shifting.

In this analysis we have presented examples of a cognitive dimension (fire-safe and fast charging), symbolic dimension (technological interest and fun), and practical dimension (practical and economic concerns, and flexibility as means to enhance physical comfort). The reasons why and ways in which the EV users in our study appropriated an EV home charging station and used it in everyday life differed, but in all cases this resulted in one kind of charging behavior or other. In sum, we find that the ways in which the charger was domesticated was not determined by the charger alone, but also by how the charger became part of the users' home life.

\section{Discussion}

Transport electrification is a central part of the Norwegian energy transition [6,7], in which the result of longstanding support policies has been a formidable increase in the fleet of EVs. It has been argued elsewhere [33] that, for different EV owners, the EV has what Pinch and Bijker [62] describe as interpretative flexibility. In this paper, we argue that the (smart) EV charger also has this kind of flexibility with regard to its domestication in households. By analyzing how the symbolic, practical, and cognitive aspects of the EV charging technology are used, we have found that the domestication process is a part of a micro-network between fire safety (in accordance with DSB recommendations), policies, the grid, and the EV owners' charging practices, all of which are aspects that interact with the economic incentive that many participants pointed to as important for participating in the pilot. This process has also made possible and led to developments in the energy service markets, where traditional electricity providers have morphed into actors that also harvest and provide flexibility upstream from household consumption.

However, even though we argue there are many indicators of an increase in the uptake of smart chargers, our findings may be limited by the recruitment strategy of the study. There are indications that our participants, who were selected from a pool of early adopters of smart charging who had been elicited by their strong interest in joining the demonstration project, were more concerned with technology and smart charging than were other members of the population in Norway. This also brings to mind the critique by Strengers, with her "resource man" [19], mentioned in "The practical and economic concerns" section. Since our participants were by no means selected from a random sample, and the sample size was small, generalization of our findings about use habits is not possible. However, such limitations are quite common in smart energy technology pilot projects, which tend to be characterized by the sort of biases described here [5]. Hence, our study provides further support to social scientists' calls to diversify technology processes of innovation in order to make results from such pilots more generalizable, while it also provides insights into a key domestication process unfolding as part of the Norwegian energy transition.

This study's relevance is also merited by its provision of insights into how the Norwegian regulations facilitate charging on dedicated chargers [38], but not dedicated smart chargers. Even if our pilot users exhibited charging habits that provided flexibility even without a smart charger, we cannot expect that all EV owners will have the same habits that reflect this grid awareness. The relevant question to follow up on is how to motivate households to procure smart chargers that ensure that they can charge during off-peak hours.

Finally, there are a number of ongoing developments in the Norwegian energy landscape, which potentially will have an impact on electricity consumption awareness and cause end users to become more flexible. The first development relates to the upcoming introduction of power tariffs. The tariffs will come online after 2022 and will cause end users to pay for high concurrent power use $(\mathrm{kW})$ rather than energy use over time $(\mathrm{kWh})$. This will be a rather fundamental change in the way Norwegians relate to their electricity consumption, and in some cases even to how, for instance water and space heating systems within households, will be designed (in many cases they are designed to work in short but incredibly high bursts). At any rate, when this introduces a strong motivation to reduce power consumption peaks throughout the day, users may start looking for loads that can be moved, such as heating, cooking and washing, and the motivation for smart 
charging will receive an added dimension. The new power tariff, and the fact that $97 \%$ of Norwegian households have installed a smart meter in their fuse box has also created a market for new types of electricity companies providing energy services. Once example of a company currently disrupting the Norwegian energy market is the Tibber, which provides real-time pricing, a smart home platform, and a smart charging that can provide of peak charging. However, our findings indicate that many users are motivated to engage in smart charging and flexibility by reasons that are not economically oriented. This begs the question as to whether smart charging and flexibility provision should be in control of demand on behalf of a third party through a smart home platform, and, if so, what would motivate different kinds of consumers to adopt the technology besides saving money?

\section{Conclusions}

The study revealed key domestication processes unfolding in the Norwegian energy transition as a consequence of the increasing numbers of EVs and corresponding grid peaks. The findings clearly indicate that users' motivations to use smart charging, such as fire-safety aspect of smart chargers, the joy and fun of using smart home technology, the practical and economic benefits, and the enhancement of physical comfort, can be as important than the economic rationale. Moreover, the findings indicated that the ways that different motivations for using smart home technology are articulated will have an impact on the potential for flexibility and grid optimization in the future. In sum, the study findings should be of interest to policymakers, smart home developers, and all others that work with end-user flexibility in the grid.

\section{Acknowledgements}

The editors and reviewers of Energy, Sustainability and Society are thanked for their constructive comments on a previous version of the paper. Thanks are also due to Catriona Turner for editing the language of this paper.

\section{Authors' contributions}

Design and data collection: IMH and WT. Analysis, writing, review and editing: IMH, WT, TMS and MR. All authors have agreed to the published version of the manuscript. All authors read and approved the final manuscript.

\section{Funding}

The study's fieldwork, analyses and writing, and the development of the smart EV pilot whit the ICT platform were funded by the European Union's Horizon 2020 Research and Innovation program under Grant Agreement No. 731148 (INVADE). The open access funding was provided by the Norwegian Centre for Energy Transition Strategies (FME NTRANS), which is funded jointly by the Norwegian Research Council (Grant Number 296205) and NTNU Sustainability.

\section{Availability of data and materials}

The authors confirm that the empirical data from the study support the findings and are available within the paper. The transcripts of all interviews are available in Norwegian and can be accessed from the corresponding author upon reasonable request.

\section{Declarations}

\section{Ethics approval and consent to participate}

The participants, all of whom were over the legal age of 18 years in Norway, took part in the study voluntarily. They provided verbal consent to participate in the study and were informed that they could withdraw at any time.

\section{Consent for publication}

Not applicable.

\section{Competing interests}

Not applicable.

Received: 21 April 2021 Accepted: 2 November 2021

Published online: 14 November 2021

\section{References}

1. Markard J (2018) The next phase of the energy transition and its implications for research and policy. Nat Energy 3(8):628-633

2. Markard J, Geels FW, Raven R (2020) Challenges in the acceleration of sustainability transitions. Environ Res Lett 15(8):081001

3. Torriti I (2020) Appraising the economics of smart meters: costs and benefits. Routledge, New York

4. Öhrlund I, Stikvoort B, Schultzberg M, Bartusch C (2020) Rising with the sun? Encouraging solar electricity self-consumption among apartment owners in Sweden. Energy Res Soc Sci 64:101424

5. Ryghaug M, Skjølsvold TM (2020) Pilot society and the energy transition: the co-shaping of innovation, participation and politics. Palgrave, Cham

6. Noel L, Zarazua de Rubens G, Kester J, Sovacool BK (2020) Understanding the socio-technical nexus of Nordic electric vehicle (EV) barriers: a qualitative discussion of range, price, charging and knowledge. Energy Policy 138:111292

7. Skjølsvold TM, Ryghaug M (2020) Temporal echoes and cross-geography policy effects: multiple levels of transition governance and the electric vehicle breakthrough. Environ Innov Soc Transit 35:232-240

8. Skjølsvold TM (2014) Back to the futures: retrospecting the prospects of smart grid technology. Futures 63:26-36

9. Ballo IF (2015) Imagining energy futures: sociotechnical imaginaries of the future smart grid in Norway. Energy Res Soc Sci 9:9-20

10. Sareen S (2020) Metrics for an accountable energy transition? Legitimating the governance of solar uptake. Geoforum 114:30-39

11. Walker G (2014) The dynamics of energy demand: change, rhythm and synchronicity. Energy Res Soc Sci 1:49-55

12. Adams S, Diamond L, Fröhlich P, Henriksen IM, Katzeff C, Ryghaug M, Yilmaz S (2021) Social license to automate: a critical review of emerging approaches to electricity demand management. Energy Res Soc Sci 80:102210

13. Fjellså IF, Silvast A, Skjølsvold TM (2021) Justice aspects of flexible household electricity consumption in future smart energy systems. Environ Innov Soc Transit 38:98-109

14. Throndsen W (2017) What do experts talk about when they talk about users? Expectations and imagined users in the smart grid. Energy Effic 10:283-297

15. Fell MJ, Shipworth D, Huebner GM, Elwell CA (2014) Exploring perceived control in domestic electricity demand-side response. Technol Anal Strateg Manag 26(10):1118-1130

16. Ensslen A, Ringler A, Dörr L, Jochem P, Zimmermann F, Fichtner W (2018) Incentivizing smart charging: modeling charging tariffs for electric vehicles in German and French electricity markets. Energy Res Soc Sci 42:112-126

17. Christensen TH, Friis F, Bettin S, Throndsen W, Ornetzeder M, Skjølsvold TM, Ryghaug M (2020) The role of competences, engagement, and devices in configuring the impact of prices in energy demand response: findings from three smart energy pilots with households. Energy Policy 137:111142

18. Ingeborgrud L, Heidenreich S, Ryghaug M, Skjølsvold TM, Foulds C, Robison R, Buchmann K, Mourik R (2020) Expanding the scope and 
implications of energy research: a guide to key themes and concepts from the social sciences and humanities. Energy Res Soc Sci 63:101398

19. Strengers Y (2013) Smart energy technologies in everyday life: smart utopia? Palgrave Macmillan, Basingstoke

20. Smale R, van Vliet B, Spaargaren G (2017) When social practices meet smart grids: flexibility, grid management, and domestic consumption in the Netherlands. Energy Res Soc Sci 34:132-140

21. Katzeff C, Wangel J (2015) Social practices, households, and design in the smart grid. In: Hilty L, Aebischer B (eds) ICT innovations for sustainability. Springer, Cham

22. Powells G, Fell MJ (2019) Flexibility capital and flexibility justice in smart energy systems. Energy Res Soc Sci 54:56-59

23. Johnson C (2020) Is demand side response a woman's work? Domestic labour and electricity shifting in low income homes in the United Kingdom. Energy Res Soc Sci 68:101558

24. Fjellså IF, Ryghaug M, Skjølsvold TM (2021) Flexibility poverty: 'locked-in' flexibility practices and electricity use among students. Energy Sources B Econ Plan Policy. https://doi.org/10.1080/15567249.2021.1937403

25. Throndsen W (2016) Response and responsibility: smart meters, end use, and the possibility of a green material public. Doctoral theses at NTNU, 2016:17. Norwegian University of Science and Technology

26. Delmonte E, Kinnear N, Jenkins B, Skippon S (2020) What do consumers think of smart charging? Perceptions among actual and potential plug-in electric vehicle adopters in the United Kingdom. Energy Res Soc Sci 60:101318

27. Schmalfuß F, Mair C, Döbelt S, Kämpfe B, Wüstermann R, Krems JF, Keinath A (2015) User responses to a smart charging system in Germany: battery electric vehicle driver motivation, attitudes and acceptance. Energy Res Soc Sci 9:60-71

28. van Noort DJ (2019) Acceptance, adoption and nudging of smart charging: influencing adoption of smart charging solutions through nudging. Master's thesis. Utrecht University

29. Ryghaug M, Skjølsvold TM (2019) Nurturing a regime shift toward electromobility in Norway. In: Finger M, Audouin N (eds) Governance of smart transportation systems: systems towards new organizational structures for the development of shared, automated, electric and integrated mobility. Springer, Cham

30. NVE (2021) Hvor kommer strømmen fra. https://www.nve.no/energi/ energisystem/kraftproduksjon/hvor-kommer-strommen-fra/?ref=mainm enu. Accessed 9 Aug 2021

31. United Nations (2015) Adoption of the Paris Agreement. https://unfccc. int/sites/default/files/english_paris_agreement.pdf. Accessed 16 Aug 2021

32. European Commission (2021) Renewable energy directive. https://ec europa.eu/energy/topics/renewable-energy/directive-targets-and-rules/ renewable-energy-directive_en. Accessed 16 Aug 2021

33. Ingeborgrud L, Ryghaug M (2019) The role of practical, cognitive and symbolic factors in the successful implementation of battery electric vehicles in Norway. Transp Res A Policy Pract 130:507-516

34. Norwegian Electric Vehicle Association (2021) Electric car sales: statistics with sales of electric cars in Norway. https://elbil.no/english/. Accessed 9 Aug 2021

35. Skotland HC, Eggum E, Spilde D (2016) Hva betyr elbiler for strømnettet? Norges vassdrag- og energidirektorat (NVE) Rapport 74-2016. Norges vassdrag- og energidirektorat, Oslo

36. Wangsness PB, Halse AH (2021) The impact of electric vehicle density on local grid costs: empirical evidence from Norway. Energy J 42(5):149-167

37. Valle M (2021) So much electricity did the EVs use last year. https://www. tu.no/artikler/sa-mye-strom-brukte-elbilene-i-fjor/507227. Accessed 16 Aug 2021

38. Direktoratet forsamfunnssikkerhetog beredskap (2019) Elsikkerhet 91. https://www.elsikkerhetsportalen.no/wp-content/uploads/2019/06/elsik kerhet-91.pdf. Accessed 16 Aug 2021

39. NEK (2018) NEK 400-7-722: Forsyning av elektriske kjøretøy. https://www. nek.no/wp-content/uploads/2017/12/NEK400-7-722_BETA_2017-12-13. pdf. Accessed 16 Aug 2021

40. Brandt AW Glansberg K (2019) Lading av elbil i parkeringsgarasje. RISErapport 2019:123. RISE (Research Institutes of Sweden), Trondheim
41. NAF (2021) How to charge the electric car safely at home and in the cabin. https://nye.naf.no/elbil/lading/slik-lader-du-elbilen-trygt-hjemme/. Accessed 16 Aug 2021

42. Sørensen KH (1994) Technology in use: two essays on the domestication of artefacts. https://www.researchgate.net/profile/Knut-Sorensen/publi cation/325628170_Technology_in_use_Two_essays_on_the_domes tication_of_artefacts/links/5b195d5a0f7e9b68b425734e/Technology-inuse-Two-essays-on-the-domestication-of-artefacts.pdf. Accessed 16 Aug 2021

43. Sørensen KH (2006) Domestication: the enactment of technology. In: Berker T, Hartmann M, Punie Y, Ward KJ (eds) Domestication of media and technology. Open University Press, Maidenhead

44. Silverstone R, Hirsch E, Morley D (1992) Information and communication technologies and the moral economy of the household. In: Silverstone $\mathrm{R}$, Hirsch E (eds) Consuming technologies: media and information in domestic spaces. Routledge, New York

45. Levold N, Spilker H (2007) Kommunikasjonssamfunnet: moral praksis og digital teknologi. Universitetsforlaget, Oslo

46. Berker T (2011) Domesticating spaces: sociotechnical studies and the built environment. Space Cult 14(3):259-268

47. Hargreaves T, Wilson C, Hauxwell-Baldwin R (2018) Learning to live in a smart home. Build Res Inf 46(1):127-139

48. Skjølsvold TM, Jørgensen S, Ryghaug M (2017) Users, design and the role of feedback technologies in the Norwegian energy transition: an empirical study and some radical challenges. Energy Res Soc Sci 25:1-8

49. Ryghaug M, Toftaker M (2014) A transformative practice? Meaning, competence, and material aspects of driving electric cars in Norway. Nat Cult 9(2):146-163

50. Throndsen W, Berker T, Knoll EB (2013) Powerhouse Kjørbo: evaluation of construction process and early use phase. SINTEF Academic Press, Oslo

51. Akrich M (1995) User representations: practices, methods and sociology. In: Rip A, Misa T, Schot J (eds) Managing technology in society: the approach of constructive technology assessment. Pinter, London

52. Woolgar S (1991) Configuring the user: the case of usability trials. In: Law $J$ (ed) A sociology of monsters: essays on power, technology and domination. Routledge, London

53. Ryghaug M, Skjølsvold TM, Heidenreich S (2018) Creating energy citizenship through material participation. Soc Stud Sci 48(2):283-303

54. Winther T, Westskog H, Sæle H (2018) Like having an electric car on the roof: domesticating PV solar panels in Norway. Energy Sustain Dev 47:84-93

55. Viseth ES (2019) 97 prosent har fått ny strømmåler: NVE krever hundre prosent i løpet av neste år. https://www.tu.no/artikler/97-prosent-harfatt-ny-strommaler-nve-krever-hundre-prosent-i-lopet-av-neste-ar/ 465397. Accessed 16 Aug 2021

56. Revold MK, Sandvik L, With ML (2018) Bolig og boforhold - for befolknigen og utsatte grupper. Statistisk sentralbyrå Rapporter 2018/13. Statistisk sentralbyrå, Kongsvinger

57. Charmaz K (2006) Constructing grounded theory. SAGE, London

58. Skjølsvold TM (2012) Curb your enthusiasm: on media communication of bioenergy and the role of the news media in technology diffusion. Environ Commun 6(4):512-531

59. Hargreaves T, Wilson C (2017) Smart homes and their users. Springer International, Cham

60. Hyysalo S, Juntunen JK, Freeman S (2013) Internet forums and the rise of the inventive energy user. Sci Technol Stud 26(1):25-51

61. Harper-Slaboszewicz P, McGregor T, Sunderhauf S (2012) Customer view of smart grid — set and forget? In: Sioshansi FP (ed) Smart grid: integrating renewable, distributed and efficient energy. Academic Press, Amsterdam

62. Pinch TJ, Bijker WE (1984) The social construction of facts and artefacts: or how the sociology of science and the sociology of technology might benefit each other. Soc Stud Sci 14(3):399-441

\section{Publisher's Note}

Springer Nature remains neutral with regard to jurisdictional claims in published maps and institutional affiliations. 